Ross, JC, G McMahon, Y Heffron, SE Adcock, SR Steadman, BS Arbuckle, A Smith, M von Baeyer 2019 Anatolian Empires: Local Experiences from Hittites to Phrygians at Çadır Höyük. Journal of Eastern Mediterranean Archaeology and Heritage Studies 7/3: 299-320.

[Text as accepted for publication; excludes figures, final redactions and page numbers. Please refer to the published article for the final version.]

\title{
Anatolian Empires: Local Experiences from Hittites to Phrygians at Çadır Höyük
}

\author{
Jennifer C. Ross, Gregory McMahon, Yağmur Heffron, Sarah E. Adcock, Sharon \\ R. Steadman, Benjamin S. Arbuckle, Alexia Smith, and Madelynn von Baeyer
}

\begin{abstract}
Çadır Höyük provides rich evidence for the endurance and transformation of specific cultural features and phenomena at a rural center on the Anatolian Plateau as it experienced the waxing and waning of control by imperial political powers of the Bronze and Iron Ages. Especially evident for those periods is the construction and maintenance of public architecture during periods of imperial power; certain economic activities also shift in their importance at those times. At the same time, continuity in economic and social organization is also a feature stretching across times of imperial control and its loss. Examination of the archaeological evidence from Çadır Höyük suggests that nothing is as continuous, nor as discontinuous, as it might seem.
\end{abstract}

KEYWORDS: Hittite Empire, Phrygian Empire, Bronze Age, Iron Age, Çadır Höyük

During the second and first millennia BCE, central Anatolia saw the rise of two major imperial powers: the Hittites, with their capital at Hattuša (modern Boğazköy or Boğazkale), and the Phrygians, centered at Gordion (modern Yassihöyük; see Fig. 1 in Steadman et al. this issue). Whether these political powers should be identified as kingdoms, states, empires, or by some other term, has been a recent subject of scholarly discussion. From the perspective of those resident in second and first millennium BCE Çadır Höyük, they would surely have seemed quite "imperial," because of their supraregional diplomatic, military, and trade activities, and hierarchical organization (Sinopoli 2001). It is from that perspective that we present the following evidence. Research on ancient empires since the late 1970s has added significant nuance to older coreperiphery models of imperial power; in particular, research has examined both the forms of imposed power (Mann 1986), and the staggering array of adjustments, from accommodation to resistance, adopted by groups that came under imperial sway (Brumfiel 2001; Earle and Smith 2012; Revell 2009; Sinopoli 2001). Çadır Höyük's long-term occupation from the Bronze Age into the Iron Age provides an opportunity to explore the issues of endurance and transformation experienced and engaged in by its residents through multiple stages of imperial domination.

Excavations and analyses at Çadır Höyük in recent years have looked at major periods of political complexity and change at the site (Steadman et al. 2019a; Ross et al. 2019; Cassis and Steadman 2014). Located on a low rise overlooking a fertile landscape (see Fig. 1 in Steadman et 
Ross, JC, G McMahon, Y Heffron, SE Adcock, SR Steadman, BS Arbuckle, A Smith, M von Baeyer 2019 Anatolian Empires: Local Experiences from Hittites to Phrygians at Çadır Höyük. Journal of Eastern Mediterranean Archaeology and Heritage Studies 7/3: 299-320.

[Text as accepted for publication; excludes figures, final redactions and page numbers. Please refer to the published article for the final version.]

al., this issue) along a river valley, Çadır offered residents, and potential conquerors, a range of advantages, including a range of natural resources, pasture and farmland, and access to roads.

\section{TRANSITIONS AND TRANSFORMATIONS: EMERGENCE OF THE HITTITES}

Extensive excavation of Late Chalcolithic Çadır Höyük (described elsewhere in this issue) has revealed significant settlement remains during a period of emergent political leadership. Following the Late Chalcolithic occupation, evidence for the Early Bronze Age is sparse, mainly coming in the form of handmade ceramics. The Middle and Late Bronze Age remains seem to represent a revival — of political complexity, construction effort, and dedication to a long-term cultural setting. With imperial powers centered "nearby," Çadır's residents experienced several different forms of interaction with the Hittite state (Table 1).

The emergence of the Hittite state in the mid- $17^{\text {th }}$ century BCE in Anatolia marks an unprecedented territorial and administrative unity, with Hattuša as capital. The historical narrative for this period suffers from an absence of texts between the end of Old Assyrian archives at Kültepe-Kaneš (1728 BCE) (Barjamovic et al. 2012) and the reign of Hattušili I (1650 BCE). The only major document extant from this time is known at the "Anitta Text" (CTH 1; Neu 1974; Hoffner 1997; McMahon 2010) written in the first person, purportedly by Anitta himself. Given that the Anitta Text is actually written in Hittite, Anitta is considered by most to be the "first" Hittite king, though little is known about this earliest Hittite figure beyond what is stated in the text. For this reason, the reign of Hattušili I has become the "artificial starting point" for Hittite historiography (Wilhelmi 2016: 224-25), which represents early Hittite state formation as sudden, rather than a gradual transition and continuity. When cuneiform was reintroduced to Anatolia in the $17^{\text {th }}$ century it was placed at the service of state administration, in the Hittite language. This is in sharp contrast to kärum period sources generated by Akkadian-speaking merchants for business records and private correspondence. Such a shift in the nature of textual visibility positions the kārum period almost as a "protohistoric" prelude to Hittite political history when Anatolia's own tradition of cuneiform literacy begins (cf. Waal 2011; 2012).

This heavily text-centered periodization is being challenged on several fronts, as a steadily growing body of evidence suggests a very narrow gap — perhaps even no gap at all—between the end of the kārum period and the beginning of Hittite administration (Gates 2017), with numerous strands of continuity, particularly in ceramic production (Schoop 2011) and iconography (Emre 2011; Özgüç 1968). Yet these trends occupy limited space in historical reconstructions of the early Hittite period, which focus on textual disruption.

Archaeological data suggest that occupational histories during the $17^{\text {th }}$ century vary from site to site, rather than adhering to a single picture of region-wide decline. While Kültepe-Kaneš did not survive the end of Old Assyrian trade, environmental factors have also been suggested for the site's final abandonment (Kulakoğlu 2014). Hattuša, by contrast, flourishes with no break in occupation, and with evidence for urban re-planning and expansion already underway in the $17^{\text {th }}$ century, possibly prior to Huattušili I (Schachner 2018). At Kaman-Kalehöyük, which rests between these two sites, the end of stratum IIIc (contemporary with Kültepe Ib) is marked by violent destruction but immediately followed by an Old Hittite sequence (Y1ldırım and Gates 2007). 
Ross, JC, G McMahon, Y Heffron, SE Adcock, SR Steadman, BS Arbuckle, A Smith, M von Baeyer 2019 Anatolian Empires: Local Experiences from Hittites to Phrygians at Çadır Höyük. Journal of Eastern Mediterranean Archaeology and Heritage Studies 7/3: 299-320.

[Text as accepted for publication; excludes figures, final redactions and page numbers. Please refer to the published article for the final version.]

Further to the east at Kayalıpınar-Šamuha, Assyrian presence is attested by cuneiform tablets that use what appears to be a Hittite measuring system, as early as the $19^{\text {th }}-18^{\text {th }}$ centuries BCE (MüllerKarpe et al. 2014).

\section{TRANSITIONS AND TRANSFORMATIONS: FROM HITTITES TO PHRYGIANS}

Once the Hittites had established their capital at Hattuša, diplomatic and military expansion spread Hittite authority and material culture more broadly over the central plateau region, including to Çadır Höyük. After a period of decline, ca. 1500-1400 BCE, featuring challenges to the ruling dynasty, the textual record indicates that the Empire Period saw further expansion, including the inclusion of the Hittite kings as major players in the diplomatic exchanges and military confrontations of the Late Bronze Age eastern Mediterranean.

On the plateau, Hittite consolidation included the construction of major administrative cities over a wide area (including Šapinuwa/Ortaköy, Šarišša/Kuşakl1, and Tapikka/Maşat Höyük), marked by public buildings and archives of cuneiform texts (Mielke 2011; Seeher 2011). Religious buildings, both large and small, rock reliefs, and a typical set of ritual objects, including ceramic vessels with painted relief decoration, were widespread. Markers of Hittite material culture and economic dominance include monumental buildings, mass-produced pottery, seals, and seal impressions. Glatz (2011) has remarked on the challenges of building an archaeological representation of Hittite power that does justice to, and can stand independent of, the textual richness of the Hittite sources. But evidence from sites from which no such textual resources derive, like Çadır Höyük, should provide a necessary counterpoint as well.

In the late decades of the Hittite Empire period, the shortcomings of the textual record begin to show: while Hittite power retracted from its maximum geographic extent, and construction of public buildings, even at the capital itself, waned, the reasons for this are unclear. While early scholarship suggested invasion and warfare, the archaeological evidence provides only meager support for this hypothesis (Seeher 2011: 379). Instead, though certain buildings were burnt at Hattuša and other major sites, causation seems to have come from within Hittite society, and worked selectively. Seeher (2010) suggests that Hittite elites abandoned the capital, rather than it suffering a major destruction. The final years of the Empire, to $1180 \mathrm{BCE}$ or later, were marked by changes to the administrative workings of society, and to their archaeological expression, as some sites were abandoned (such as Tapikka and Šarišša), some rebuilt along less monumental lines (Hattuša), and still others occupied without significant interruption (like Çadır itself) (Mielke 2011; Ross et al. 2019).

Depending on one's geographic location, then, the end of the Hittite Empire might have felt more like a bump or a bang. The Early Iron Age (ca. 1100-900 BCE) in central Anatolia saw distinct regional cultural trajectories, the origins or causes of which are unclear due to a lack of texts. But occupation of some Hittite sites, including Hattuša itself, as well as smaller sites like Çadır Höyük, continued, signaling adaptation to these changes and resiliency among non-elite inhabitants of the region (Ross et al. 2019; Seeher 2010). 
Ross, JC, G McMahon, Y Heffron, SE Adcock, SR Steadman, BS Arbuckle, A Smith, M von Baeyer 2019 Anatolian Empires: Local Experiences from Hittites to Phrygians at Çadır Höyük. Journal of Eastern Mediterranean Archaeology and Heritage Studies 7/3: 299-320.

[Text as accepted for publication; excludes figures, final redactions and page numbers. Please refer to the published article for the final version.]

During the Middle (900-550 BCE) and Late (550-330 BCE) Iron Ages, centralized political power again emerged on the Anatolian plateau, shifting west to Gordion, the center of Phrygian rule. Where the Phrygians originally came from remains a debated topic, although most evidence and scholarship puts their origin in Thrace (Sams 1988, 2011; Sevin 1991; Voigt 2011). The archaeological remains at Phrygian Gordion reveal a hierarchical society, with significant centralized control over at least some economic production, and major effort put into public and monumental architecture (Voigt 2007). By late in the Middle Iron Age and early Late Iron Age, such public architecture was being built elsewhere on the plateau as well, with evidence at Hattuša (Genz 2007) and Kerkenes (Kealhofer and Grave 2011; Summers and Summers 2013). Phrygian inscriptions in public spaces at the latter site suggest the extension of Phrygian control to areas close to Çadır Höyük. At the same time, regional ceramic styles predominated, with Phrygian gray wares typical at Gordion (Henrickson 1994; Sams 1994), while painted Alişar IV wares characterized the area around Çadır Höyük, though these are not found at Kerkenes (Draycott and Summers 2008: xiii). Phrygian power eventually declined, due to political and military pressure from the south and east (Neo-Assyrian, and later Persian incursions into northern Syria and Anatolia) and the west (Lydian, and later Greek expansion). How these conflicts were experienced at sites within the Phrygian orbit is sometimes clear, as evidenced by the final destruction of Gordion (Voigt 2011: 1086) and the burning and abandonment of Kerkenes; yet even the identity of Kerkenes's destroyers remains in question.

\section{TRANSITIONS AND TRANSFORMATIONS: SETTLEMENT AND ARCHITECTURAL PATTERNS AT ÇADIR HÖYÜK}

\section{Occupied Areas}

The $32 \mathrm{~m}$ high mound at Çadır Höyük is 5 hectares in area; excavations on the mound slopes have accessed pre-Byzantine remains. Bronze and Iron Age architecture and features have been found on the north, east, and south sides of the mound (see Fig. 1 for relevant trenches; recent work on the western slope, not shown in Fig. 1, suggests there may be second and first millennium occupation there as well; Fig. 2 shows the excavations on the southern slope). While this overview suggests long-term continuity of occupation, there are indications that the focus of settlement shifted over time; not all phases are represented in all locations, and the types of buildings also changed during these centuries. Middle and Late Bronze Age remains, as well as those of the Late Iron Age, are found on the northern and eastern slopes, though they are best represented on the east slope. The south slope, by contrast, had some Late Bronze Age occupation (but no Middle Bronze), which then continued into the Early Iron Age, a phase found nowhere else yet on the mound. Limited Late Iron Age features on the south slope are mostly buried under the extensive Byzantine remains at the top of the mound, but the Middle Iron Age is represented by over two meters of deposit here. These shifts may represent the contraction and expansion of population over time, as well as changing administrative needs, but they also reflect varying construction materials and types. 
Ross, JC, G McMahon, Y Heffron, SE Adcock, SR Steadman, BS Arbuckle, A Smith, M von Baeyer 2019 Anatolian Empires: Local Experiences from Hittites to Phrygians at Çadır Höyük. Journal of Eastern Mediterranean Archaeology and Heritage Studies 7/3: 299-320.

[Text as accepted for publication; excludes figures, final redactions and page numbers. Please refer to the published article for the final version.]

\section{Types of Buildings}

Excavations at Çadır Höyük have revealed an Old Hittite settlement enclosed by a city wall and destroyed by fire, which in turn overlies earlier strata belonging to the kārum period (Gorny 2006; Steadman et al. 2013). The ancient name of Çadır Höyük remains debated (see Gorny 2018), but its proximity to Alişar, which is most likely the wabartum station of Amkuwa (=Hittite Ankuwa) (Barjamovic 2011: 310-15), places it securely within the kārum circuit. This very proximity may have meant that Çadır did not house an Assyrian community of its own, but continued life as an ordinary Anatolian town. Construction of the fortifications began as a $2 \mathrm{~m}$ wide casemate wall with stone foundations and a mudbrick superstructure (Fig. 3; Steadman and McMahon 2015: 83-84). Alişar was fortified at the same time, also with a casemate wall (von der Osten 1937).

In subsequent centuries, Çadır's wall was repeatedly rebuilt, each time stepping back slightly toward the interior of the mound, and each time with considerable stone-robbing from the earlier levels. The final version, dating to the Hittite Empire period (Fig. 4), was 3-4 m wide in some areas, and may no longer have been entirely casemate in form. This wall, like the earlier one, extended to the northern slope, where there was a large gate (based on the size and configuration of the in situ stones) (Steadman, McMahon, and Ross 2019); the wall also ran, in mudbrick only, to the south. No entrances or buttresses appear on the south side; in USS 4, the top of the brickwork spread over $4 \mathrm{~m}$ in thickness in some places, perhaps including a platform extending from the wall inside the settlement.

Inside the Hittite fortifications on the eastern side of the mound at Çadır at least two levels of occupation have been identified. The first, dating to the earlier Hittite Empire or later Old Hittite period, features a large building (only the very eastern end of which is revealed, while the rest extends into the western baulk), resting on a foundation consisting of stones and wooden beams (Steadman and McMahon 2017). Two courtyards sit in front of what must have been the eastern entrance to the structure. The size and construction of this building suggests that it was public rather than domestic. This building fell out of use and a layer (over $1.2 \mathrm{~m}$ in depth) of clay and mudbrick fill created a new occupational layer, likely dating to the later Hittite Empire period, on which domestic structures with an attached courtyard were built (Steadman and McMahon 2015).

Materials dating to the very end of the Late Bronze Age come only from the southern slope of Çadır, and offer a very different perspective on the use of the mound. Here, residents of the town during the last century of Hittite control pursued industrial activities, likely seasonal or annual use of a set of plastered brick facilities to remelt copper alloy (Fig. 5; Steadman and McMahon 2017; Ross et al. 2019). Pyrotechnological activities were already practiced on the southern slope; a number of hearths and ovens spread over a large area of the Late Chalcolithic southern town were used in cooking, pottery production, and metallurgy (Steadman and McMahon 2015: 82). This tradition continued even into the Byzantine period, indicated by the discovery of metal slag and a tuyère in a room atop the slope (Steadman et al. 2019b).

The industrial use of this part of the site continued into the Early Iron Age, but new features and finds suggest that the industries changed after Hittite imperial power withdrew from the region (Ross et al. 2019). Specifically, no metallurgical by-products (slag or prills) come from the Early Iron Age layers; rather, a series of plastered depressions, with tools and faunal remains suggestive 
Ross, JC, G McMahon, Y Heffron, SE Adcock, SR Steadman, BS Arbuckle, A Smith, M von Baeyer 2019 Anatolian Empires: Local Experiences from Hittites to Phrygians at Çadır Höyük. Journal of Eastern Mediterranean Archaeology and Heritage Studies 7/3: 299-320.

[Text as accepted for publication; excludes figures, final redactions and page numbers. Please refer to the published article for the final version.]

of leather and felt production, dominate the area (Fig. 6a, b). These animal-based industries, notoriously difficult to identify archaeologically, were then replaced in the Middle Iron Age by clearer evidence for wool-working, including thread and textile production; the total number of loom weights recovered is low, but they were made from unbaked clay, and may have been missed in excavation, while assorted spindle whorls have been recovered. Paved walkways connected work areas, and stone foundations delineated somewhat ephemeral enclosures (Fig. 7; Ross 2010). Also dating to the Middle Iron Age are some significant wall sections, including perhaps one arm of a gate whose foundation was stone.

The final centuries of the Iron Age are poorly represented on the southern slope. Glassy slag in fills suggests the continued use of this part of the site for industrial purposes. By contrast, more substantial portions of the fortifications survive on the east and north sides, along with paved pathways leading to one or more gates or other types of entrance (Steadman and McMahon 2015: 89-90; Steadman, McMahon and Ross 2019). These limited remains are reminiscent of late Middle Iron and early Late Iron Age Kerkenes, though on a significantly smaller scale.

\section{ENDURANCE: TECHNOLOGY AND SUBSISTENCE THROUGH TIME}

Although the major political changes of the second and third millennia BCE had impacts on the physical form and layout of Çadır Höyük, the site also provides considerable evidence of continuity over the same timespan. In the realms of artifact production, diet, and resource use, Çadır's residents relied on long-term traditions and ecological persistence to shape the material world of their daily lives. While imperial rule appears to have affected the spatial layout of the settlement, and therefore people's bodily experience of political control as they moved through the site, its effects on domestic activities appear to have been significantly fewer. In some cases outlined below, the withdrawal of imperial control correlates with a return to more traditional and efficient methods of production, suggesting an undercurrent of custom and self-sufficiency that was stronger than politics.

\section{Ceramics and Other Technologies at Çadır Höyük}

The ceramic assemblages at Çadır Höyük (Fig. 8) changed significantly over time, and yet specific production techniques, forms, and methods of decoration regularly reappeared. During the Middle and Late Bronze Age, the ceramic repertoire at Çadır aligned closely with assemblages from other Hittite sites, including Boğazköy (cf. Fischer 1963; Müller-Karpe 1988; Schoop 2006, 2011), featuring mass-produced Hittite drab ware for wheelmade open and closed shapes (Fig. 8, a-b). Large jars and pithoi were handmade. Much of the assemblage was likely locally-made, using a mica-rich clay source that had long-term popularity at the site. At the same time, very few Hittite fine wares have been recovered (Ross et al. 2019: 26), probably a sign that there was little elite demand for more expensive and/or imported wares, or their contents.

The following transitional phase (dating to the very end of the LB) features a different array of ceramic forms and manufacturing techniques. This is, in part, because the area on the southern slope from which these vessels derive was non-domestic, serving functions that did not require as many serving and cooking vessels. Some of the ceramics coming from the final LB levels on the south slope were clearly industrial in function: handmade, flat-based trays, with heavy burning, 
Ross, JC, G McMahon, Y Heffron, SE Adcock, SR Steadman, BS Arbuckle, A Smith, M von Baeyer 2019 Anatolian Empires: Local Experiences from Hittites to Phrygians at Çadır Höyük. Journal of Eastern Mediterranean Archaeology and Heritage Studies 7/3: 299-320.

[Text as accepted for publication; excludes figures, final redactions and page numbers. Please refer to the published article for the final version.]

made from unsorted gritty clay (Fig. 8, e). The assemblage includes both wheelmade and handmade forms, some nicely slipped and burnished, made from a different fabric from the drab ware, one that included plenty of vegetal temper (Fig. 8, c-d; Ross et al. 2019).

Once the Early Iron Age began, the site saw a drop in the number of wheelmade vessels, though wheel production never entirely disappeared. Open forms predominated, especially bowls (shallow and deep) with a pink or red burnished slip atop a paste with heavy vegetal temper. Most of the pottery of the Early Iron Age was low-fired, suggesting small-scale production and firing in open pits. Vessels with buff fabric and slip, and painted decoration, are rare in excavated contexts, though they do occur in surface finds. Genz (2005) noted the similarity of these forms and decorative patterns at Çadır and Hattuša to EB III handmade pottery ("Cappadocian Ware"; Orthmann 1963) found at sites on the plateau. Such a return to earlier techniques of ceramic manufacture applies equally well to the red/pink-slipped and burnished bowls with vegetal temper, which have Early Bronze Age precedents (though rare at Çadır), and black-burnished handmade vessels, some with knobs and/or incised decoration, that look and feel like Late Chalcolithic pottery.

The Middle and Late Iron Age ceramics at Çadır belong firmly within the Alişar IV tradition, with wheelmade forms predominating, and plenty of examples of painted motifs. Several sherds of Alişar-type "stag ware" have been found (Fig. 8, f-g). Larger vessels could be coil-made or even slab-constructed. By the Late Iron Age (Fig. 8, h-i), storage jars with one or more raised horizontal bands (for gripping?) and white slip were common. Fine wares include well-fired jars with moderately thin walls, brown burnished slip, and bichrome designs painted atop a whitepainted panel; motifs include floral designs and geometric patterns. Such pottery also appears in the Middle Phrygian levels at Gordion (Henrickson 2005: 131). Instrumental Neutron Activation Analysis (INAA) study of Iron Age pottery from Çadır indicates that a variety of fabrics were utilized at the site, perhaps denoting individual producers with their own clay sources, or changes over time to the clays and recipes; Late Iron Age Çadır also featured a number of imported pots (Kealhofer et al. 2010).

Beyond ceramics, other technologies attested at Çadır imply long-term continuity, reliant on local resources and traditional ways of doing and making things. One prominent feature at Çadır, and likely at other sites (but typically unreported) is the reuse of ceramic sherds for a variety of functions - from jar stoppers and lids to tools. At Çadır, nearly every phase of occupation, going back to the Chalcolithic, features some form and degree of this recycling process. Consistent pitdigging and recovery of building stones from earlier levels means the residents of Çadır regularly encountered older, broken vessels, though they recycled sherds from their own assemblages as well.

We recognize these pieces through modifications to their shapes, and due to abrasion, wear, or modification of one or more edges (Fig. 9). Particular patterns of use are evident. In the second millennium levels on the eastern slope of the site, the Hittite residents used broken handles and attached body sherds from jars; these were found heavily abraded and coated in plaster, suggesting a use in spreading and, perhaps, burnishing lime plaster on walls and floors (Fig. 9, a-b). On the south slope, flat body sherds were shaped in a range of ways: in the Early Iron Age levels, many had been abraded, while some were chipped down like lithic tools for a sharp cutting edge (Fig. 9, 
Ross, JC, G McMahon, Y Heffron, SE Adcock, SR Steadman, BS Arbuckle, A Smith, M von Baeyer 2019 Anatolian Empires: Local Experiences from Hittites to Phrygians at Çadır Höyük. Journal of Eastern Mediterranean Archaeology and Heritage Studies 7/3: 299-320.

[Text as accepted for publication; excludes figures, final redactions and page numbers. Please refer to the published article for the final version.]

c). These may have been used as scrapers, to deflesh hide or smooth wood. By the Middle and Late Iron Age, rounded sherds are prominent, some with central holes, others broken in the process of making those holes (Fig. 9, d). These objects could be used as spindle whorls, or even as loom weights in the hypothesized textile production in the later levels.

As the political fortunes of towns on the plateau changed, metallurgical production shifted in various ways, as supplies of metal were limited and metals were in demand by central powers. Hittite texts indicate that taxes could be paid in metal, typically copper (Siegelová and Tsumoto 2011: 280). But even in Hittite territory, the metals themselves seem to have been worked in autonomous workshops, indicative of a low level of control exercised by administrators over production (Lehner and Schachner 2017). For most rural towns, it seems unlikely that any fulltime smiths would have found enough supply or demand to remain self-sufficient. At Çadır, lowlevel, probably seasonal production of metal items is suggested by the installation found in the final Late Bronze Age levels in USS 4, and by the small numbers of finished metal objectsmostly tools and ornaments - found in all phases of the Middle Bronze through Iron Age occupation.

Finally, there is substantial evidence for the production of clothing from animal products. While the specific products and technologies changed over time, Çadır's residents likely produced leather and textile items regularly, mostly at a small scale, but at least during the Iron Age, utilizing the southern slope area for hide-scraping, felt-processing, wool-working, and likely dyeing and fulling (Ross 2010). This may have been away from the main residential areas of the site, and selected (many times over the millennia) because prevailing winds could blow odors away from the rest of the site. While Middle Iron Age Gordion saw the separation of elite textile production areas from the beginning and end stages of production (Burke 2005), at a small site like Çadır, the installations for wool preparation, textile-making, and finishing were concentrated, likely serving a small group of skilled but part-time producers for local distribution and consumption. The various technologies practiced at Çadır during the Bronze and Iron Ages underwent constant adjustments to changing supplies of materials and demand by local and non-local customers. But the overall trends suggest that small-scale, traditional productive techniques predominated.

\section{Diet and Ecological Resources}

Plant-based Subsistence

Archaeobotanical samples of second and first millennium date derive mainly from the southern slope of the site. During both the Hittite and Iron Age occupations, important cereal crops at Çadır include Triticum durum/aestivum (durum/bread wheat) and Hordeum sp. (barley); T. turgidum L. ssp. dicoccum (Schrank) Thell. (formerly referred to as $T$. dicoccum, emmer) and $T$. monococcum L.(einkorn) were also encountered. Commonly recovered legume crops include Lens culinaris Medik. (lentil), Pisum sp. (pea), and Vicia ervilia (L.) Willd. (bitter vetch) (Smith 2007). At Kaman-Kalehöyük in central Anatolia, a similar range of crops was grown, with the addition of Cicer arietinum L. (chickpea), which does not feature prominently within the samples from Çadır (Fairbairn and Omura 2005). Fairbairn and Omura (2005) argue that the presence of large Hittite storage pits at Kaman-Kalehöyük (resembling textual descriptions of ÉSAG storage facilities) indicate the centralized control of grain distribution by the Hittite state. At Çadır the 
Ross, JC, G McMahon, Y Heffron, SE Adcock, SR Steadman, BS Arbuckle, A Smith, M von Baeyer 2019 Anatolian Empires: Local Experiences from Hittites to Phrygians at Çadır Höyük. Journal of Eastern Mediterranean Archaeology and Heritage Studies 7/3: 299-320.

[Text as accepted for publication; excludes figures, final redactions and page numbers. Please refer to the published article for the final version.]

remains of what appears to be the base of a Hittite-period silo, located near a Hittite period house containing a storage jar (Gorny et al. 2002) may be the more "rural" version of such a system. By the Iron Age, a large number of plaster-lined pits were exposed that contained abundant wood charcoal. Together, these features provide an excellent opportunity to examine cooking, fuel use, and industrial practices.

\section{Fuel Use}

In recent years, archaeobotanical studies of ancient fuel management and use have yielded deep socio-cultural and economic insights (Smith et al. 2015). During the second and first millennia BCE, wood and dung fuel were the most obvious choices within central Anatolia. At Çadır, hearths, trash and other pits appear to be dominated by wood, suggesting that wood was the fuel of choice within these features. Hearths in the second millennium also appear to contain greater proportions of domesticated plants, indicating that they were used, in part, for cooking, while ovens appear to contain a greater proportion and diversity of chaff parts (including culm and basal culm fragments, spikelet forks and rachis fragments) and weed seeds that may be associated with the use of dung fuel, possibly to prepare bread; this would suggest different fuel choices for various types of heating and cooking needs, a pattern observed also at Ubaid period Tell Zeidan (Smith et al. 2018). This variation may reflect a changing supply of wood and other fuel resources during the later second millennium.

It is notable that wood was heavily used as a fuel during the Hittite occupation at Çadır as there is evidence to suggest that some parts of the plateau were experiencing a reduction of tree cover. Anthracological studies of wood remains from Kaman-Kalehöyük indicate low taxa richness associated with the Hittite state, followed by a dramatic increase in the presence of pine beginning in the Iron Age (Wright et al. 2015). Wright et al. (2015: 228) argue that the Hittite occupants of Kaman-Kalehöyük substantially affected their surroundings, intensively harvesting open woodland while actively avoiding pine. A similar pattern seems to be evident at Çadır. By the later Iron Age, wood was used heavily in the construction of plaster lined pits and may have served an important industrial function, but was used less in hearths/cooking areas where dung may have prevailed. This may represent a community adjusting to changes in their surrounding landscape, making judicious choices to best serve their daily needs.

\section{Faunal Evidence}

To date, approximately 6,500 animal bone specimens dating from the Old Hittite period through the Late Iron Age have been recorded by the faunal team at Çadır Höyük. General information about the Bronze and Iron Age materials, including species counts and a discussion of relative species frequencies can be found elsewhere (Ross et al. 2019; Steadman et al. 2019a). Broadly speaking, the assemblage is dominated by the Near Eastern "barnyard" domesticates: cattle, caprines (sheep and goats), and pigs. A look at the management of cattle and caprines at Çadır during the second and first millennia BCE provides a better understanding of how the local economy was affected by broader shifts in political organization on the Anatolian plateau during this span of time. Evidence for age at death, specifically the state of fusion of long bone epiphyses 
Ross, JC, G McMahon, Y Heffron, SE Adcock, SR Steadman, BS Arbuckle, A Smith, M von Baeyer 2019 Anatolian Empires: Local Experiences from Hittites to Phrygians at Çadır Höyük. Journal of Eastern Mediterranean Archaeology and Heritage Studies 7/3: 299-320.

[Text as accepted for publication; excludes figures, final redactions and page numbers. Please refer to the published article for the final version.]

and also biometric data, allows us to address changes in body size reflecting the sex and age composition of the animals consumed and deposited on the mound.

Age at death was monitored diachronically from the Hittite period through the Late Iron Age. For cattle, sheep, and goats, long bone epiphyses generally fuse by around four years of age (Popkin et al. 2012; Silver 1963; Zeder 2006). This approach therefore can be useful for differentiating management systems focused on producing secondary products such as animal fiber and traction, which tend to result in the slaughter of high frequencies of adult animals (Payne 1973; Redding 1984).

Fusion results for cattle and caprines can be found in Table 2. Because of the small size of the samples identified specifically to sheep or goat, fusion states of these taxa are combined for this analysis. In the case of cattle, only $14-17 \%$ of specimens displayed unfused epiphyses in the Hittite and Middle and Late Iron Age samples, with the frequency of unfused specimens decreasing to less than four percent in the Early Iron Age. Each of these periods is therefore characterized by a focus on the consumption of aged cattle, suggesting that animals were primarily managed for secondary products and were only slaughtered after extensive use as labor or dairy animals.

The pattern for caprines is quite different. Here we see a consistent increase in the percentage of unfused bones from the mid-second millennium through the first millennium. In the Hittite period only $23 \%$ of caprines were slaughtered prior to epiphyseal fusion, increasing to $31 \%$ and $34 \%$ in the Early and Middle Iron Ages, and $41 \%$ by the Late Iron Age. This pattern likely reflects changes in caprine herd management practices over time. Lower frequencies of juveniles are associated with secondary products, especially fiber production, which may have been a focus of Hittite period caprine production at the site. This emphasis on adult animals slowly declined following the Hittite "collapse," perhaps reflecting a shift to a production strategy focused more on juvenile animals presumably for primary products such as meat.

A second analytical approach examined changes in the body sizes of cattle, sheep, and goats over time. Measurements (following von den Driesch 1976) were analyzed and compared to one another with the help of the logarithmic size index (LSI), which allows measurements from different skeletal parts to be compared by calculating the log difference of the natural logs of each measurement and a "standard" animal.

Boxplots tracing patterns of body size over time for cattle, sheep, and goats are presented in Fig. 10. Cattle size (Fig. 10, top) is generally consistent across the Hittite Period and in the Early Iron Age (excluding the largest specimen, which likely represents an aurochs). ${ }^{2}$ It is likely that specimens close to or smaller than 0 on the LSI scale represent females. In the Hittite period, most of the cattle are larger than the standard, suggesting the presence of a high proportion of bulls and/or oxen. In addition, many specimens are well above the standard, indicating the presence of very large male cattle. The largest Hittite specimen is within the size range of Middle Eastern aurochs (Gourichon and Helmer 2008), as are the largest of the Early Iron Age specimens, suggesting continuity in wild bull hunting across the Hittite/Iron Age transition. Cattle size decreases in the Middle Iron Age and Late Iron Age. In these periods, specimens close to the size of the standard increase in abundance, suggesting that bulls and oxen are less well represented and cows were more frequently consumed. Moreover, the very large animals of the Hittite and Early Iron periods are no longer present in the Middle and Late Iron Age. 
Ross, JC, G McMahon, Y Heffron, SE Adcock, SR Steadman, BS Arbuckle, A Smith, M von Baeyer 2019 Anatolian Empires: Local Experiences from Hittites to Phrygians at Çadır Höyük. Journal of Eastern Mediterranean Archaeology and Heritage Studies 7/3: 299-320.

[Text as accepted for publication; excludes figures, final redactions and page numbers. Please refer to the published article for the final version.]

For caprines, sheep size decreases from the Late Bronze into the Early and Later Iron Age (Fig. 10, center). ${ }^{3}$ In this case, the standard animal is a wild female sheep. In the Hittite period, most specimens are at or above the standard, indicating that both male and female sheep exhibited robust body sizes. In the Iron Age, this robusticity declines, with notable decreases in the size of the smallest specimens, perhaps suggesting a change in the sheep population in the first millennium BCE. In the case of goats (Fig. 10, bottom), there are no significant changes in body size from the Hittite period and across the Iron Age. ${ }^{4}$ Goats exhibit small body sizes in all periods with more small females and fewer large males, suggesting that young male culling was common practice.

Overall, our data allow us to identify patterns of change and continuity in livestock management in the Late Bronze Age and Iron Age at Çadır Höyük. For cattle, juvenile animals were rarely culled, suggesting that secondary products were the focus of cattle management in all periods. A focus on large oxen is further reflected in the large size of cattle across the Late Bronze/Early Iron transition. In the Middle and Late Iron Age, however, cattle size declines and smaller females are more abundant, suggesting significant reorientation of the agro-pastoral system perhaps characterized by less intensive agricultural production (i.e., fewer oxen).

Faunal evidence for sheep management shows a combination of an increase in the frequency of juveniles and a decrease in body size over time, suggesting a shift from fiber production in the Late Bronze Age to a more generalized production of sheep in the Iron Age. These changes seem to coincide with the Late Bronze/Early Iron Age transition, after which a new population of smaller bodied sheep seems to be present. In contrast to sheep and cattle, goat management does not exhibit obvious changes over time, instead reflecting a remarkable degree of continuity from the Late Bronze Age into the Late Iron Age. This may reflect the fact that goat management remained a conservative, risk reduction strategy through these periods. Since they seem less connected to regional commodity markets (Zeder 1991), goat management may have been insulated from changes in regional political and economic systems that affected sheep and cattle production systems.

\section{CONCLUSION}

Combining evidence from settlement and building patterns, craft technologies, crop and animal management, and fuel use, we see the second and first millennium BCE occupation at Çadır Höyük as exhibiting both continuity and change as the imperial powers centered near the site expanded and contracted. Patterns of change, including the types of buildings constructed, and an economic focus on particular productive techniques and herd management during periods of imperial domination, suggest a degree of political control. Still, even at these times, and during transitional phases between major political powers on the Anatolian plateau, Çadır Höyük's residents maintained traditional social and economic systems, with little evidence for differentiation or upheaval.

\section{REFERENCES CITED}

Barjamovic, G. 2011. A Historical Geography of Ancient Anatolia in the Assyrian Colony Period. Copenhagen: Museum Tusculanum Press.

--, T. K. Hertel, and M. T. Larsen. 2012. Ups and Downs at Kanesh: Chronology, History and Society in the Old Assyrian Period. Istanbul: NINO. 
Ross, JC, G McMahon, Y Heffron, SE Adcock, SR Steadman, BS Arbuckle, A Smith, M von Baeyer 2019 Anatolian Empires: Local Experiences from Hittites to Phrygians at Çadır Höyük. Journal of Eastern Mediterranean Archaeology and Heritage Studies 7/3: 299-320.

[Text as accepted for publication; excludes figures, final redactions and page numbers. Please refer to the published article for the final version.]

Brumfiel, E. M. 2001. Aztec Hearts and Minds: Religion and the State in the Aztec Empire. In Empires: Perspectives from Archaeology and History, ed. S. E. Alcock, T. N. D’Altroy, K. D. Morrison, and C. M. Sinopoli, 283-310. Cambridge: Cambridge University Press.

Burke, B. 2005. Textile Production at Gordion and the Phrygian Economy. In The Archaeology of Midas and the Phrygians: Recent Work at Gordion, ed. L. Kealhofer, 69-81. Philadelphia: University of Pennsylvania Museum of Archaeology and Anthropology.

Cassis, M., and S. Steadman. 2014. Çadır Höyük: Continuity and Change on the Anatolian Plateau. In East to West: Current Approaches to Medieval Archaeology, ed. S. Stull, 140-154. Newcastle upon Tyne: Cambridge Scholars Publishing.

Draycott, C. M., and G. D. Summers. 2008. Sculpture and Inscriptions from the Monumental Entrance to the Palatial Complex at Kerkenes Dağ, Turkey. Oriental Institute Publication 135. Chicago: Oriental Institute of the University of Chicago.

Earle, T., and M. E. Smith. 2012. Household Economies under the Aztec and Inka Empires. In The Comparative Archaeology of Complex Societies, ed. M. E. Smith, 238-84. Cambridge: Cambridge University Press.

Emre, K. 2011. The Traces of Kültepe/Kanesh in Hittite Art. In Anatolia's Prologue: Kültepe Kanish Karum, ed. F. Kulakoğlu and S. Kangal, 154-59. Kayseri: Kayseri Metropolitan Municipality.

Fairbairn, A., and S. Omura. 2005. Archaeological Identification and Significance of ÉSAG (Agricultural Storage Pits) at Kaman-Kalehöyük, Central Anatolia. Anatolian Studies 55:15-23.

Fischer, F. 1963. Die Keramik. Boğazköy-Hattuša 75. Die Hethitische Keramik von Boğazköy Wissenschaftliche Veröffentlichungen der Deutschen Orient-Gesellschaft 75. Berlin: Mann.

Gates, M.-H. 2017. Gods, Temples, and Cult at the Service of the Early Hittite State. In At the Dawn of History: Studies in Honour of J. Nicholas Postgate, ed. Y. Heffron, A. Stone, and M. J. Worthington, 189-210. Winona Lake, IN: Eisenbrauns.

Genz, H. 2005. Thoughts on the Origin of the Iron Age Pottery Traditions in Central Anatolia. In Anatolian Iron Ages 5. Proceedings of the Fifth Anatolian Iron Ages Colloquium held at Van, 6-10 August 2001, ed. A. Çilingiroğlu and G. Darbyshire, 75-84. Ankara: British Institute at Ankara.

--------. 2007. Late Iron Age Occupation on the Northwest Slope at Boğazköy. In Anatolian Iron Ages 6. The Proceedings of the Sixth Anatolian Iron Ages Colloquium held at Eskişehir, 16-20 August 2004, ed. A. Çilingiroğlu and A. Sagona, 135-51. Leuven: Peeters.

Glatz, C. 2011. The Hittite State and Empire from Archaeological Evidence. In The Oxford Handbook of Ancient Anatolia, ed. S. R. Steadman and G. McMahon, 877-99. Oxford: Oxford University Press.

Gorny, R. L., G. McMahon, S. Paley, S. Steadman, and B. Verhaaren. 2002. The 2000 and 2001 Seasons at Çadır Höyük in Central Turkey: A Preliminary Report. Anatolica 28: 109-34. --. 2006. The 2002-2005 Excavation Seasons at Çadır Höyük. The Second Millennium Settlements. Anatolica 32:29-54. 
Ross, JC, G McMahon, Y Heffron, SE Adcock, SR Steadman, BS Arbuckle, A Smith, M von Baeyer 2019 Anatolian Empires: Local Experiences from Hittites to Phrygians at Çadır Höyük. Journal of Eastern Mediterranean Archaeology and Heritage Studies 7/3: 299-320.

[Text as accepted for publication; excludes figures, final redactions and page numbers. Please refer to the published article for the final version.]

2018. Reconsidering the Location of Mt. Puškurunuwa and Other Issues of Central Anatolian Geography. In Assyriomania and More. In Memory of Samuel M. Paley, ed. F. Pedde and N. Shelley, 129-78. Münster: Zaphon.

Gourichon, L., and D. Helmer. 2008. Étude archéozoologique de Mureybet. In Le site néolithique de Tell Mureybet (Syrie du Nord), ed. J. J. Ibánez, 115-228. BAR International Series 1843. Oxford: BAR.

Henrickson, R. C. 1994. Continuity and Discontinuity in the Ceramic Tradition of Gordion during the Iron Age. In Anatolian Iron Ages 3: The Proceedings of the Third Anatolian Iron Ages Colloquium Held at Van, 6-12 August 1990, ed. A. Çilingiroğlu and D. H. French, 95-129. London: British Institute of Archaeology at Ankara.

---------. 2005. The Local Potter's Craft at Phrygian Gordion. In The Archaeology of Midas and the Phrygians: Recent Work at Gordion, ed. L. Kealhofer, 124-35. Philadelphia: University of Pennsylvania Museum of Archaeology and Anthropology.

Hoffner, H. A. 1997. Proclamation of Anitta of Kušš. In The Context of Scripture, Vol. 1, ed. W. W. Hallo and K. L. Younger, Jr., 182-84. Leiden: Brill.

Kealhofer, L., and P. Grave. 2011. The Iron Age on the Central Anatolian Plateau. In The Oxford Handbook of Ancient Anatolia, ed. S. R. Steadman and G. McMahon, 415-442. Oxford: Oxford University Press.

---------, P. Grave, B. Marsh, S. Steadman, R. L. Gorny, and G. D. Summers. 2010. Patterns of Iron Age Interaction in Central Anatolia: Three Sites in Yozgat Province. Anatolian Studies 60: 71-92.

Kulakoğlu, F. 2014. Kanesh after the Assyrian Colony Period: Current Research at Kültepe and the Question of the End of the Bronze Age Settlement. In Current Research at KültepeKanesh: An Interdisciplinary and Integrative Approach to Trade Networks, Internationalism, and Identity, ed. L. Atıc1, F. Kulakoğlu, G. Barjamovic, and A. Fairbairn, 85-94. Atlanta: Lockwood Press.

Lehner, J. W., and A. Schachner. 2017. The Organization of Metal Production at Hattuša: A First Assessment. In Overturning Certainties in Near Eastern Archaeology: A Festschrift in Honor of K. Aslıhan Yener, ed. Ç. Maner, M. T. Horowitz, and A. S. Gilbert, 403-435. Leiden: Brill.

Mann, M. 1986. The Sources of Social Power. Vol. I: A History of Power from the Beginning to A.D. 1760. Cambridge: Cambridge University Press.

McMahon, G. 2010. Agency, Identity, and the Hittite State. In Agency and Identity in the Ancient Near East, ed. S. R. Steadman and J. C. Ross, 181-89. London: Equinox.

Mielke, D. P. 2011. Key Sites of the Hittite Empire. In The Oxford Handbook of Ancient Anatolia, ed. S. R. Steadman and G. McMahon, 1031-1054. Oxford: Oxford University Press.

Müller-Karpe, A. 1988. Hethitische Töpferei der Oberstadt von Hattuša. Marburger Studien 10. Marburg-Lahn: Hitzeroth Verlag.

-----------, V. Müller-Karpe, and G. Kryszat. 2014. Untersuchungen in Kayalıpınar 2013 und 2014. Mitteilungen der Deutschen Orient-Gesellschaft zu Berlin 146: 11-41.

Neu, E. 1974. Der Anitta-Text. Studien zu den Bogazköy-Texten 18. Wiesbaden: Harassowitz. 
Ross, JC, G McMahon, Y Heffron, SE Adcock, SR Steadman, BS Arbuckle, A Smith, M von Baeyer 2019 Anatolian Empires: Local Experiences from Hittites to Phrygians at Çadır Höyük. Journal of Eastern Mediterranean Archaeology and Heritage Studies 7/3: 299-320.

[Text as accepted for publication; excludes figures, final redactions and page numbers. Please refer to the published article for the final version.]

Orthmann, W. 1963. Frühe Keramik von Boğazköy aus den Ausgrabungen am Nordwesthang von Büyükkale. Wissenschaftliche Veröffentlichungen der Deutschen Orient-Gesellschaft 74. Berlin: Mann.

Özgüç, N. 1968. Kaniş Karumu Ib Katı Mühürleri ve Mühür Basklarl/Seals and Seal Impressions of Level Ib from Karum Kanish. Ankara: Türk Tarih Kurumu.

Payne, S. 1973. Kill-off Patterns in Sheep and Goats: The Mandibles from Aşvan Kale. Anatolian Studies 23: 281-303.

Popkin, P. R. W., P. Baker, F. Worley, S. Payne, and A. Hammon. 2012. The Sheep Project (1): Determining Skeletal Growth, Timing of Epiphyseal Fusion and Morphometric Variation in Unimproved Shetland Sheep of Known Age, Sex, Castration Status and Nutrition. Journal of Archaeological Science, 39(6): 1775-1792.

Redding, R. 1984. Theoretical Determinants of a Herder's Decisions: Modeling Variation in the Sheep/Goat Ratio. In Animals and Archaeology, Vol. 3, Early Herders and Their Flocks, ed. J. Clutton-Brock and C. Grigson, 223-241. Oxford: British Archaeology Review.

Revell, L. 2009. Roman Imperialism and Local Identities. Cambridge: Cambridge University Press.

Ross, J. C. 2010. Çadır Höyük: The Upper South Slope 2006-2009. Anatolica 36: 67-87.

-------, S. R. Steadman, G. McMahon, S. E. Adcock, and J. W. Cannon. 2019. When the Giant Falls: Endurance and Adaptation at Çadır Höyük in the Context of the Hittite Empire and Its Collapse. Journal of Field Archaeology 44:1: 19-39.

Sams, G. K. 1988. The Early Phrygian Period at Gordion: Toward a Cultural Identity. Source 7(3/4): 9-15.

----------. 1994. The Early Phrygian Pottery. The Gordion Excavations, 1950-1973: Final Reports

IV. Philadelphia: University Museum, University of Pennsylvania.

-----------. 2011. Anatolia: The First Millennium B.C.E. in Historical Context. In The Oxford Handbook of Ancient Anatolia, ed. S. R. Steadman and G. McMahon, 604-22. Oxford: Oxford University Press.

Schachner, A. 2018. Assur Ticaret Kolonileri Çă̆ı'ndaki Hattuş/The City of Hattuš during the Old Assyrian Trade Colonies Period. In Assurlular: Dicle'den Toroslar'a Tanrı Assur'un Kralliğl / The Assyrians: Kingdom of the God Aššur from Tigris to Taurus, ed. K. Köroğlu and S.F. Adalı, 84-105. İstanbul: Yap1 Kredi Yayınları.

Schoop, U.-D. 2006. Dating the Hittites with Statistics: Ten Pottery Assemblages from BogazköyHattusa. BYZAS 4: 215-39

----------. 2011. Hittite Pottery: A Summary. In Insights into Hittite History and Archaeology, ed. H. Genz and D.P. Mielke, 241-75. Leuven: Peeters.

Seeher, J. 2010. After the Empire: Observations on the Early Iron Age in Central Anatolia. In ipamati kistamati pari tumatimis: Luwian and Hittite Studies Presented to J. David Hawkins on the Occasion of his $70^{\text {th }}$ Birthday, ed. I. Singer, 220-229. Tel Aviv: Tel Aviv University. ----------. 2011. The Plateau: The Hittites. In The Oxford Handbook of Ancient Anatolia, ed. S. R. Steadman and G. McMahon, 376-392. Oxford: Oxford University Press.

Sevin, V. 1991. The Early Iron Age in the Elaziğ Region and the Problem of the Mushkians. Anatolian Studies 41: 87-97. 
Ross, JC, G McMahon, Y Heffron, SE Adcock, SR Steadman, BS Arbuckle, A Smith, M von Baeyer 2019 Anatolian Empires: Local Experiences from Hittites to Phrygians at Çadır Höyük. Journal of Eastern Mediterranean Archaeology and Heritage Studies 7/3: 299-320.

[Text as accepted for publication; excludes figures, final redactions and page numbers. Please refer to the published article for the final version.]

Siegelová, J. and H. Tsumoto. 2011. Metals and Metallurgy in Hittite Anatolia. In Insights into Hittite History and Archaeology, ed. H. Genz and D. P. Mielke, 275-300. Leuven: Peeters.

Silver, I. 1963. The Ageing of Domestic Animals. In Science in Archaeology: A Comprehensive Survey of Progress and Research, ed. D. Brothwell and E. Higgs, 250-268. London: Thames and Hudson.

Sinopoli, C. 2001. Empires. In Archaeology at the Millennium: A Sourcebook, ed. G. M. Feinman and T. D. Price, 439-71. New York: Kluwer Academic/Plenum Publishers.

Smith, A. 2007. Plant Use at Çadır Höyük, Central Anatolia Anatolica 33:169-184.

--------, K. Dotzel, J. Fountain, L. Proctor, and M. von Baeyer. 2015. Examining Fuel Use in Antiquity: Archaeobotanical and Anthracological Approaches in Southwest Asia. Ethnobiology Letters 6:192-195.

----------, L. Proctor, T. C. Hart, and G. J. Stein. 2018. The burning issue of dung in archaeobotanical samples: a case-study integrating macro-botanical remains, dung spherulites, and phytoliths to assess sample origin and fuel use at Tell Zeidan, Syria. Vegetation History and Archaeobotany. 10.1007/s00334-018-0692-9.

Steadman, S. R. and G. McMahon. 2015. Recent Work (2013-2014) at Çadır Höyük on the North Central Anatolian Plateau. In The Archaeology of Anatolia: Recent Work (2011-2014), Volume 1, ed. S. R. Steadman and G. McMahon, 69-97. Newcastle upon Tyne: Cambridge Scholars Publishing.

----------, and G. McMahon. 2017. Recent Work (2015-2016) at Çadır Höyük on the North Central Anatolian Plateau. In The Archaeology of Anatolia: Recent Work (2015-2016), Volume 2, ed. S. R. Steadman and G. McMahon, 94-117. Newcastle upon Tyne: Cambridge Scholars Publishing.

---------, G. McMahon, B. S. Arbuckle, M. von Baeyer, A. Smith, B. Yıldırım, L.D. Hackley, S. Selover, and S. Spagni. 2019a. Stability and Change at Çadır Höyük: A Case of Late Chalcolithic Globalisation?. Anatolian Studies 69: 21-57.

---, G. McMahon, and J. C. Ross. 2019. Chalcolithic, Iron Age, and Byzantine Investigations at Çadır Höyük: The 2017 and 2018 Seasons. In The Archaeology of Anatolia: Recent Work (2017-2018), Vol, III, forthcoming. Newcastle upon Tyne: Cambridge Scholars Publishing.

-, G. McMahon, J. C. Ross, M. Cassis, J. D. Geyer, B. Arbuckle, and M. von Baeyer. 2013. The 2009 and 2012 Seasons of Excavation at Çadır Höyük on the Anatolian North Central Plateau. Anatolica 39: 113-67.

---------, G. McMahon, T. E. Şerifoğlu, M. Cassis, A. J. Lauricella, L. D. Hackley, S. Selover, B. Yıldırım, B. S. Arbuckle, M. von Baeyer, Y. Heffron, K. Tardio, S. Adcock, E. Dinç, G. Özger, B. Selvi, S. Offutt, and A. Hartley. 2019b. The 2017-2018 Seasons at Çadır Höyük on the North Central Plateau. Anatolica 45: forthcoming.

Summers, G. D., and F. Summers. 2013. The Kale at Kerkenes Dağ: An Iron Age Capital in Central Anatolia. In Cities and Citadels in Turkey: From the Iron Age to the Seljuks, ed. S. Redford and N. Ergin, 137-59. Leuven: Peeters.

Uerpmann, M., and H-P. Uerpmann. 1994. Animal Bone Finds from Excavation 520 at Qala'at alBahrain. In Qala'at al-Bahrain Volume 1: The Northern City Wall and the Islamic 
Ross, JC, G McMahon, Y Heffron, SE Adcock, SR Steadman, BS Arbuckle, A Smith, M von Baeyer 2019 Anatolian Empires: Local Experiences from Hittites to Phrygians at Çadır Höyük. Journal of Eastern Mediterranean Archaeology and Heritage Studies 7/3: 299-320.

[Text as accepted for publication; excludes figures, final redactions and page numbers. Please refer to the published article for the final version.]

Fortress, ed. F. Højlund and H. H. Andersen, 417-444. Jutland Archaeological Society Publications 30.1. Aarhus: Jutland Archaeological Society.

Voigt, M. M. 2007. The Middle Phrygian Occupation at Gordion. In Anatolian Iron Ages 6. The Proceedings of the Sixth Anatolian Iron Ages Colloquium held at Eskişehir, 16-20 August 2004, ed. A. Çilingiroğlu and A. Sagona, 311-33. Leuven: Peeters.

---------. 2011. Gordion: The Changing Political and Economic Roles of a First Millennium B.C.E. City. In The Oxford Handbook of Ancient Anatolia, ed. S. R. Steadman and G. McMahon, 1069-94. Oxford: Oxford University Press.

von den Driesch, A. 1976. A Guide to the Measurements of Animal Bones from Archaeological Sites. Peabody Museum Bulletin 1: 1-136.

von der Osten, H. H. 1937. The Alishar Hüyük Seasons of 1930-32. Part I. Oriental Institute Publications 28. Chicago: University of Chicago Press.

Waal, W. 2011. They Wrote on Wood. The Case for a Hieroglyphic Scribal Tradition on Wooden Writing Boards in Hittite Anatolia. Anatolian Studies 61: 21-34.

---------. 2012. Writing in Anatolia: The Origins of the Anatolian Hieroglyphs and the Introductions of the Cuneiform Script. Altorientalische Forschungen 39/2: 287-315.

Wilhelmi, L. 2016. Materiality and Presence of the Anitta Text in Original and Secondary Context. Considerations on the Original Nature of the Proclamation of Anitta $(C T H 1)$ and Its Transmission as Part of Hittite Traditional Literature. In Materiality of Writing in Early Mesopotamia, ed. T.E. Balke and C. Tsouparopoulou, 223-39. Berlin: De Gruyter.

Wright, N. J., A. S. Fairbairn, J. T. Faith, and K. Matsumura. 2015. Woodland Modification in Bronze and Iron Age Central Anatolia: An Anthracological Signature for the Hittite State? Journal of Archaeological Science 55:219-230.

Y1ldırım, B., and M.-H. Gates. 2007. Archaeology in Turkey 2004-2005. American Journal of Archaeology 111/2: 275-356.

Zeder, M. A. 1991. Feeding Cities: Specialized Animal Economy in the Ancient Near East. Washington: Smithsonian Institution Press.

---------. 2006. Reconciling Rates of Long Bone Fusion and Tooth Eruption and Wear in Sheep (Ovis) and Goat (Capra). In Recent Advances in Ageing and Sexing Animal Bones, ed. D. Ruscillo, 87-118. Oxford: Oxbow Press. 
Ross, JC, G McMahon, Y Heffron, SE Adcock, SR Steadman, BS Arbuckle, A Smith, M von Baeyer 2019 Anatolian Empires: Local Experiences from Hittites to Phrygians at Çadır Höyük. Journal of Eastern Mediterranean Archaeology and Heritage Studies 7/3: 299-320.

[Text as accepted for publication; excludes figures, final redactions and page numbers. Please refer to the published article for the final version.]

\footnotetext{
${ }^{1}$ Sheep and goat standards are taken from Uerpmann and Uerpmann (1994), whereas the cattle standard represents a nineteenth century Pinzgau cow skeleton (SAPM-MA-01254) housed at the Institut für Palaeoanatomie, Domestikationsforschung und Geschichte der Tiermedizin, Ludwig-Maximilians Universität München.

${ }^{2}$ Old Hittite mean $=0.028$; Middle/Late Hittite mean $=0.024$; Early Iron Age mean $=0.032$.

${ }^{3}$ A one-way ANOVA test indicates that the difference in size between the Hittite and Early Iron Age specimens is just above the significance threshold $(\mathrm{p}=0.051)$.

${ }^{4}$ Hittite mean $=-0.079$; Early Iron mean $=-0.059$; Middle $/$ Late Iron $=-0.061$ (one-way ANOVA $p=0.32$ ).
} 